\title{
Marine macro algal diversity of St. Mary's Island, Karnataka, India
}

\author{
S. K. Yadav* and M. Palanisamy ${ }^{1}$
}

*Botanical Survey of India, Headquarters, CGO Complex, Kolkata 700 064, West Bengal 'Botanical Survey of India, Southern Regional Centre, Coimbatore - 641 003, Tamil Nadu *Corresponding author: skyadavbsic@gmail.com

\section{भारत के कर्नाटक स्थित सेंट मैरी द्वीप की समुद्री वृहद शैवालीय विविधता}

\section{एस के यादव एवं एम पलनीसामी}

\section{सारांश}

कर्नाटक राज्य स्थित सेंट मेरी द्वीप बहुतायत में पत्थरीले प्राकृतवासों से भरा पड़ा है, जो समुद्री वृहद शैवालों (समुद्री खरपतवारों) की समृद्ध विविधता को आश्रय देते हैं। वर्ष 2014-2017 के दौरान, इस द्वीप कें कई क्षेत्रीय अन्वेष्ण दौरों के दौरान समुद्री वृहद शैवाल के 52 टैक्सा संग्रहित एवं अभिलेखित किए गए, जिसमें 16 जातियां क्लोरोफायसी, 19 फियोफायसी एवं 17 जातियां रोडोफायसी कुल से सम्बधित हैं। इन अभिलेखों की गहन संवीक्षा से ज्ञात होता है कि यह शोध द्वीप से संबंधित समुद्री वृहद शैवाल विविधता पर सबसे पहली व्यापक प्रस्तुति है। प्रस्तुत शोधपत्र शैवालीय विविधता एवं जैवविविधता संरक्षण के लिए इस द्वीप के महत्त्व का विश्लेषण करता है।

\section{ABSTRACT}

The St. Mary's Island, located in the state of Karnataka is endowed with enormous rocky habitats and support rich diversity of marine macro algae (seaweeds). During the years 2014-2017, several extensive field explorations were undertaken to this Island and 52 taxa of marine macro algae, comprising of 16 Chlorophyceae, 19 Phaeophyceae and 17 Rhodophyceae were recorded. The thorough scrutiny of literature shows that this is the first comprehensive report on the marine macro algal diversity from this island. This paper analyses the algal diversity and significance of this Island for biodiversity conservation.

Keywords: Chlorophyceae, Marine Macro Algae, Phaeophyceae, Rhodophyceae, St Mary's Island

\section{INTRODUCTION}

Algae are the group of primitive, usually aquatic plants and constitute an important component of the biodiversity. The marine macro algae, also known as seaweeds, are mostly liphophilic in nature and grow mainly on rocky substrata in shallow, intertidal and sub-tidal regions and even up to a depth of $150 \mathrm{~m}$ (Markager \& Sand-Jensen, 1994). Since times ago, seaweeds are used by human beings in the form of food and fodder. Though, algae are primitive and mostly minute in size, they play a key role in sustainability of the marine ecosystems, provide food and breeding grounds for the aquatic fauna and produce significant quantity of oxygen in the atmosphere. Besides, they are also economically very important and support the livelihood of the people. Globally, c. 11,000 taxa of seaweeds have been reported (https://www.seaweed.ie; http://www.algaebase.org), of which c. 221 taxa have been recognized as economically important in various forms like food, fodder and in industries such as agaragar, agaroids, algin, carageenans, cosmetics, manure (SLF), rubber, paper products, pharmaceutical, textile, dairy, biofuel etc. In India, c. 865 taxa of marine macro 
algae, comprising of 442 taxa of Rhodophyceae, 212 taxa of Chlorophyceae and 211 taxa of Phaeophyceae (Rao \& Gupta, 2015). Among these, c. 94 taxa (42 Rhodophyceae, 35 Chlorophyceae and 17 Phaeophyceae) are recognized as economically important (Yadav, 2020). Therefore, considering its biological and economical importance, the study on the marine algal diversity throughout the world has got momentum in the recent years.

The St. Mary's island (Fig 1) is located in the Udupi district of Karnataka and lies in Arabian Sea in the west coast of India. It is a group of four islands, around $5-6 \mathrm{~km}$ off the coast of Malpe city in Udupi district. The largest island is the St. Mary's island. It is also known as Coconut Island because of the dominance of the coconut trees. Whereas, the remaining three small islands are known as North Island, Darya Bahadurgarh Island and South Island. Historically, St. Mary's island was named by Vasco-da-Gama, a Portuguese explorer and the first European to reach India, when he landed at this island in 1498. The highest elevation is $c .10 \mathrm{~m}$

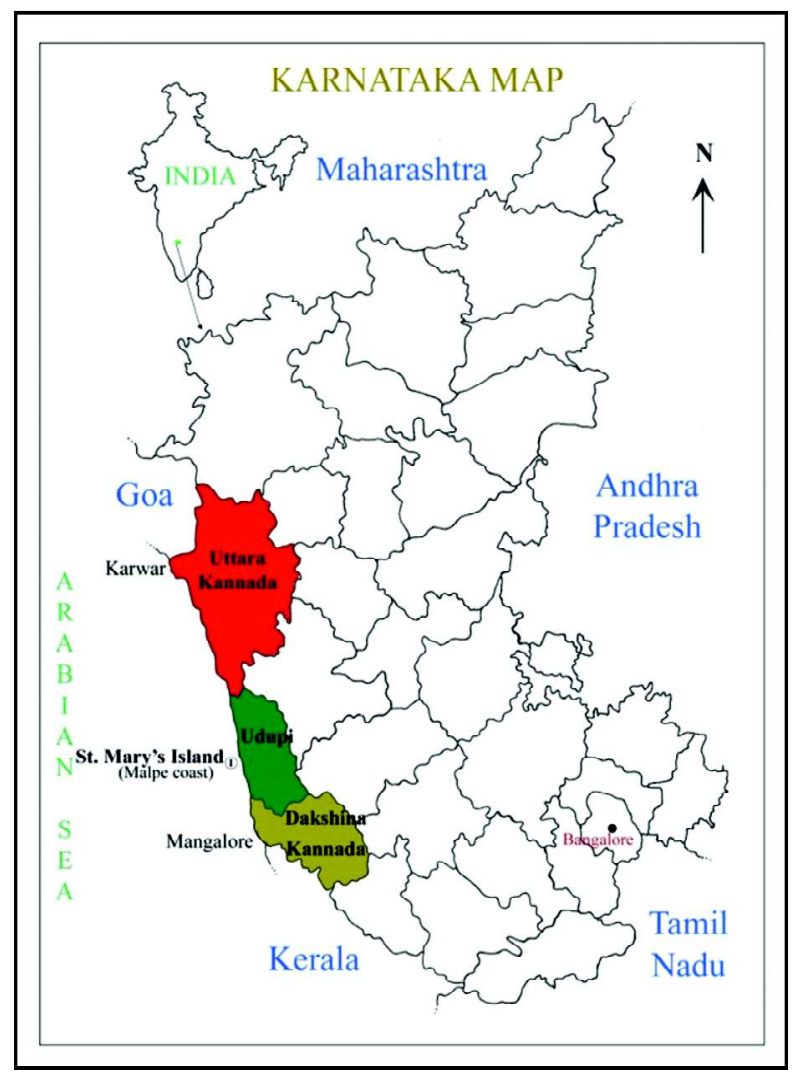

Fig. 1: Map showing location of St. Mary's Island in Karnataka coast

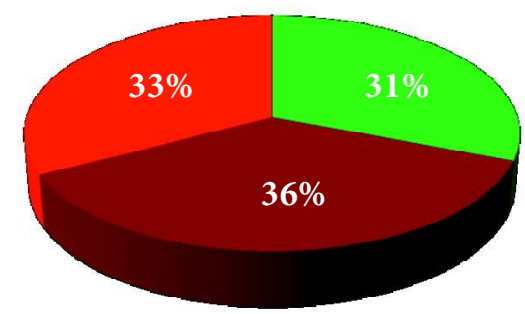

Chlorophyceae

Phaeophyceae

Rhodophyceae

Fig.2 : Pie chart showing diversity of seaweeds at St. Mary's Island.

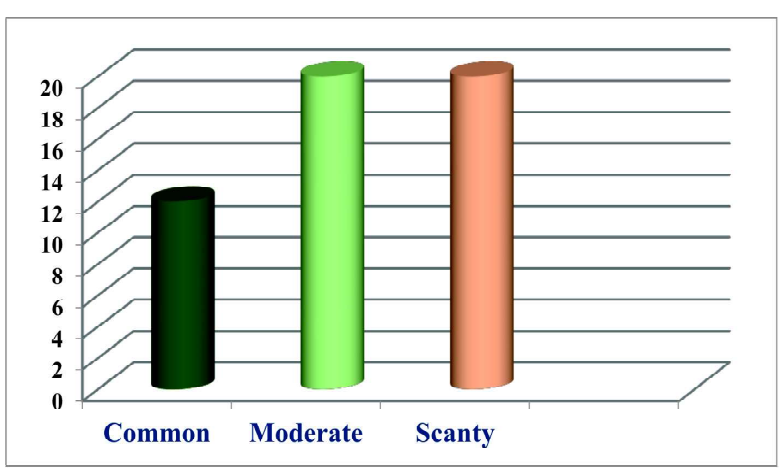

Fig. 3: Graph showing distributional abundance of seaweeds at St. Mary's Island.

height. The island is $c .500 \mathrm{~m}$ in length and $100 \mathrm{~m}$ in width. Geologically, this island is considered as very important as it was formed around 88 million years ago by sub-aerial sub-volcanic activity, when Madagascar was attached to India (Subramanya, 2009). The rocks are of characteristically columnar type of up to $6 \mathrm{~m}$ long with hexagonal to polygonal shape (Plate 1). Considering the importance and rarity of such rocks, Geological Survey of India (GSI) recognized this island as one of the 4 geological monuments in Karnataka state and one of the 26 geological monuments of India in 2001 (Kamath, 2002).

The St. Mary's island is naturally endowed with excellent abundance of natural rocks and habitats, supported with lush green vegetation of coconut groves. These unique feature of the island supports the occurrence of not only marine algae, but also several angiosperms, bryophytes, pteridophytes and fauna like colonies of gulls, sandpipers, crows, brahminy kites 

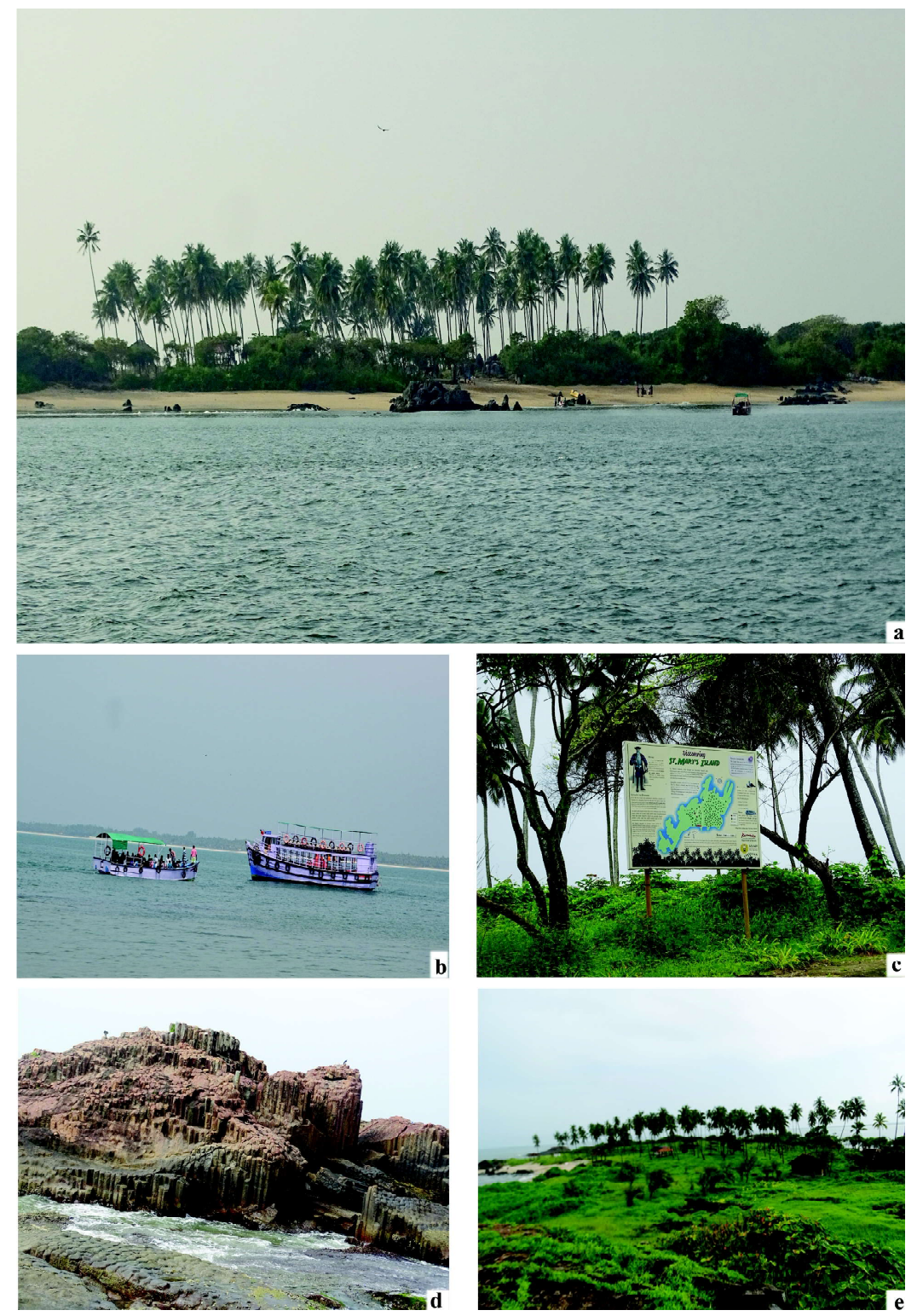

Plate 1 - Nature of the Island: a. Panoramic view of St. Mary's Island; b. Boats used to reach at the Island; c. A display board showing information about the Island; $\mathbf{d}$. Columnar besalt rocks; e. Coconut groves and green vegetation.

(Haliastur indus), egrets, green bee-eaters and many more birds and other animals (Plate $1 \& 2$ ). Perusal of literature reveals that the research works on the biodiversity account of this island is almost negligible and only few sporadic reports are available. Recently, Palanisamy \& Yadav (2017) and Yadav \& Palanisamy (2020) reported few new records of marine macro algae from Karnataka coast. Therefore, in continuation of the study, an attempt has been made here to provide the diversity of marine macro algae (seaweeds) of this island for the first time.

\section{MATERIALS AND METHODS}

During the study period between 2014-2017, several field explorations were conducted to this island in different seasons for the survey and collection of marine macro algae. The algal samples were collected randomly during low tides and kept in plastic zipped covers / containers. All the collected specimens were thoroughly washed with fresh water and carefully sorted out into three groups i.e. Chlorophyceae, Phaeophyceae and Rhodophyceae. The selected samples were 

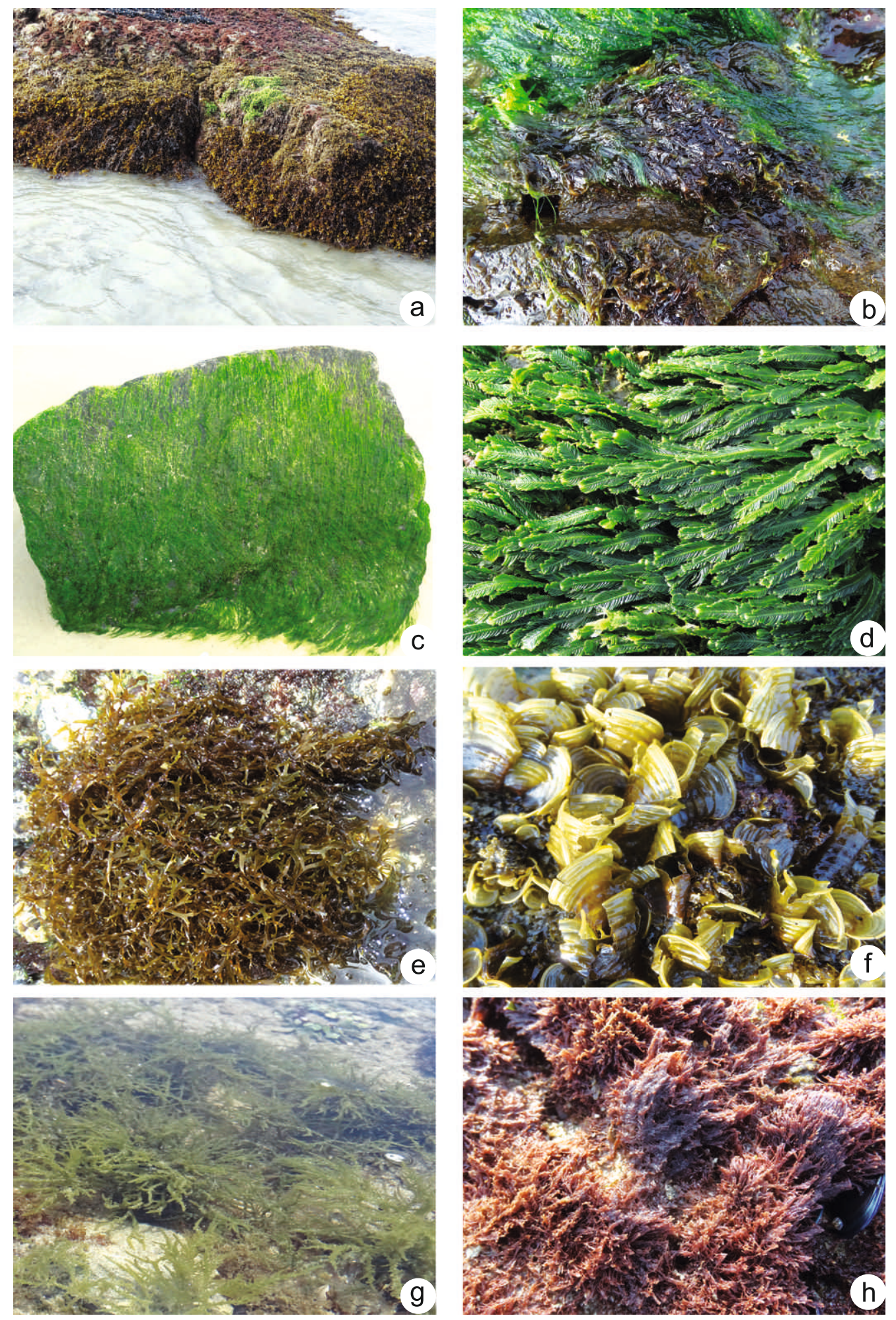

Plate 2. Seaweeds vegetation: a. An exposed rock showing luxuriant vegetation; b. Mixed growth of Ulva (green) and Porphyra (red) forming slippery layer on rocks; c. Ulva flexuosa Wulfen; d. Caulerpa taxifolia (Vahl) C. Agardh; e. Canistrocarpus cervicornis (Kuetz.) De Paula \& De Clerck; f. Padina tetrastromatica Hauck; g. Hypnea musciformis (Wulfen) J.V. Lamour.; h. Centroceras clavulatum (C. Agardh) Mont. 
poisoned in 4\% formalin and 1\% Ethyl alcohol solution and herbarium sheets were prepared for each species following the standard methods. The representative samples were preserved in wet forms for anatomical studies. All the preserved specimens were examined carefully under microscopes. Identification and nomenclature of the specimens were confirmed following the standard literatures (Srinivasan, 1969, 1973; Desikachary \& al., 1990, 1998; Silva \& al., 1996; Krishnamurthy, 2000; Kraft, 2007, 2009; Krishnamurthy \& Baluswamy, 2010; Huisman, 2015) while author names of taxa are based on Brummitt \& Powel, 1992. All the wet and dry preserved specimens are deposited at the Madras Herbarium ( $\mathrm{MH})$, Botanical Survey of India, Southern Regional Centre, Coimbatore, Tamil Nadu.

\section{RESULTS AND DISCUSSION}

\section{Seaweed diversity}

During the study period, 102 field numbers of marine algae were collected from the rocky substrata of the St. Mary's Island. After critical study of these specimens, 52 taxa of marine macro algae, comprising of 16 Chlorophyceae, 19 Phaeophyceae and 17 Rhodophyceae (Table 1) were enumerated. The result (Fig 2) shows that among the recorded algae, Phaeophyceae (36\%) is dominant, followed by Rhodophyceae (33\%) and Chlorophyceae (31\%). The study shows the significant diversity of seaweeds at this Island.

\section{Distribution pattern}

The present study also reveals ample variation in the occurrence and vegetation patterns of the marine macro algae. Among the 52 taxa recorded, 12 were distributed commonly at most of the sampling units, while 20 were moderate and 20 as scanty (very few in numbers) in distribution (Fig 3). The commonly distributed taxa are mostly species of Ulva i.e U. compressa L., U. flexuosa Wulfen, U. lactuca L. (U. fasciata Delile), U. prolifera O.F. Muell., Chaetomorpha antennina (Bory) Kuetz., Caulerpa taxifolia (Vahl) C. Agardh, Dictyota dichotoma (Huds.) J.V. Lamour., Padina tetrastromatica Hauck, Sargassum tenerrimum J. Agardh, Gelidium micropterum Kuetz., Hypnea musciformis (Wulfen) J.V. Lamour., Centroceras clavulatum (C. Agardh) Mont.

\section{Seasonal variations}

Among the various factors such as substratum, water quality, temperature, salinity, TDS which affect the seaweeds occurrence, seasons also play a significant role. During the present study, it has been observed that post monsoon is considered as the best season for seaweed diversity. Among the 52 taxa recorded, significantly 42 taxa were found growing during the post monsoon season, whereas 21 taxa were recorded during both the monsoon and post monsoon seasons, 13 taxa during both the post-monsoon and summer seasons, 3 taxa during the summer season and 7 taxa recorded as common throughout year. The highest diversity of seaweeds during the monsoon and post monsoon seasons is because of the water qualities and temperature. During this period, because of the heavy rain and influx of fresh water (rain, river, stream etc.) the DO (Dissolved Oxygen) value of seawater increases whereas $\mathrm{pH}$, salinity, TDS and surface water temperature decrease, which escalate the nutrient value of seawater and promote algal vegetation, particularly green algae (Chlorophyceae). However, during the summer season, brown algae (Phaeophyceae) and red algae (Rhodophyceae) were found more common.

\section{DISCUSSION}

The St. Mary's Island has geological significance because of the presence of its columnar type hexagonal to polygonal shaped rocks and recognition by the Geological Survey of India (GSI) as one of the important geological monuments in Karnataka (www.gsi.gov.in; Kamath, 2002). However, the perusal of literature reveals that the biodiversity profile of the Island was not surveyed and documented properly. Therefore, in the present study, it has been attempted to bring out the first comprehensive record of marine macro algal diversity of this Island. The study shows the presence of 52 taxa, naturally supported with suitable rocky substrata. The study highlights the significance of this Island for algal vegetation in proper and biodiversity in general. Therefore, considering its importance in biodiversity and geological perspectives, the St. Mary's Island should be conserved and monitored properly and more such research should be undertaken regularly in order to get more information about its biodiversity.

\section{ACKNOWLEDGEMENTS}

Authors are thankful to the Director, Botanical Survey of India, Kolkata, the Scientist-in-charge, Technical 
TABLE 1. List of the marine macro algae enumerated at St. Mary's island, Karnataka, India.

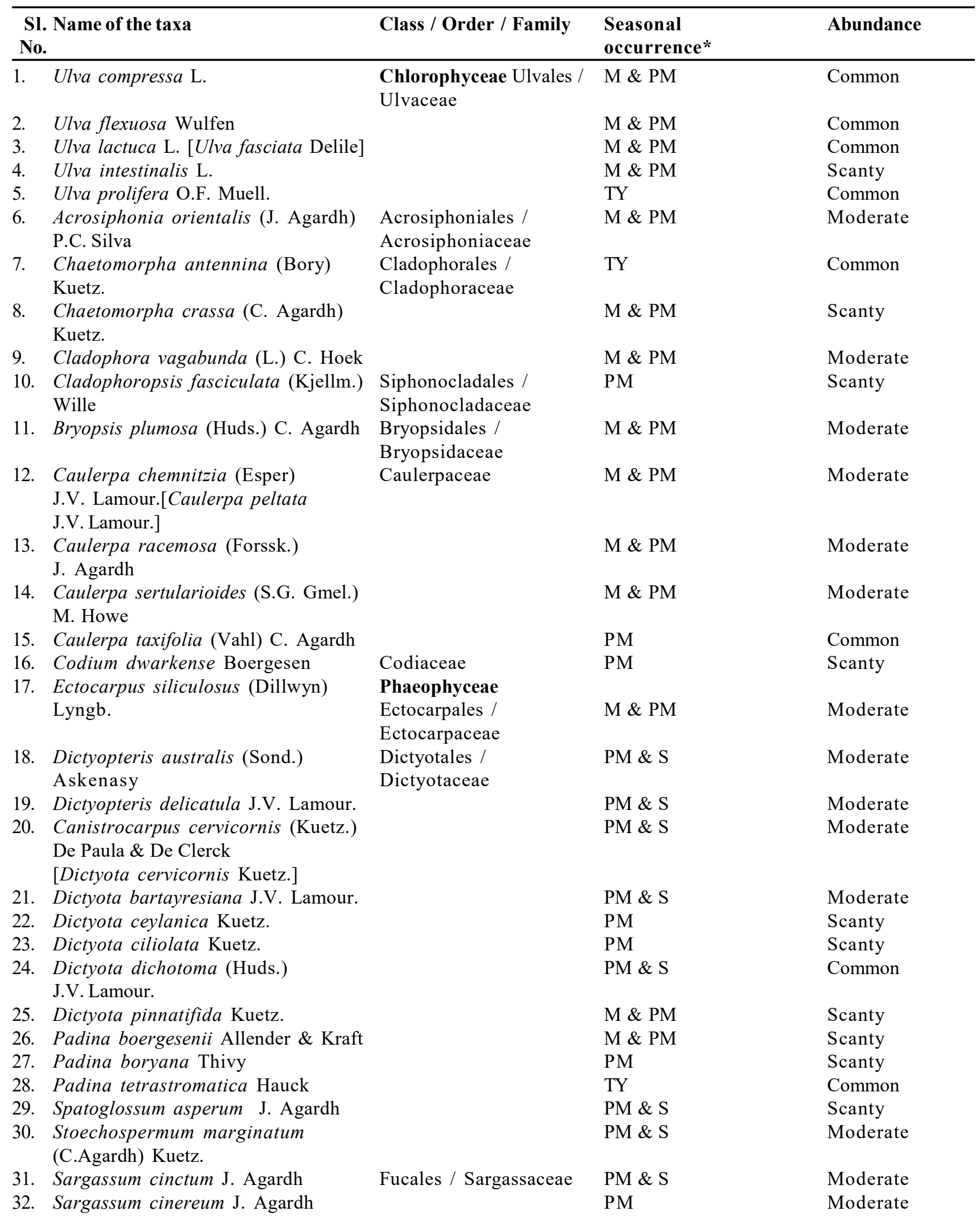




\begin{tabular}{|c|c|c|c|}
\hline $\begin{array}{l}\text { Sl. Name of the taxa } \\
\text { No. }\end{array}$ & Class / Order / Family & $\begin{array}{l}\text { Seasonal } \\
\text { occurrence* }\end{array}$ & Abundance \\
\hline $\begin{array}{l}\text { 33. Sargassum ilicifolium (Turner) } \\
\text { C.Agardh [Sargassum cristaefolium } \\
\text { C. Agardh] }\end{array}$ & & $M \& P M$ & Scanty \\
\hline 34. Sargassum polycystum C. Agardh & & $\mathrm{PM} \& \mathrm{~S}$ & Scanty \\
\hline 35. Sargassum tenerrimum J. Agardh & & $\mathrm{PM} \& \mathrm{~S}$ & Common \\
\hline $\begin{array}{l}\text { 36. Porphyra vietnamensis } \\
\text { Tak. Tanaka \& P.H. Ho }\end{array}$ & $\begin{array}{l}\text { Rhodophyceae Bangiales / } \\
\text { Bangiaceae }\end{array}$ & $\mathrm{M} \& \mathrm{PM}$ & Moderate \\
\hline $\begin{array}{l}\text { 37. Gelidium micropterum Kuetz. } \\
\text { 38. Gelidium pusillum (Stackh.) Le Jolis } \\
\text { 39. Gracilaria corticata (J. Agardh) }\end{array}$ & $\begin{array}{l}\text { Gelidiales / Gelidiaceae } \\
\text { Gracilariales / }\end{array}$ & $\begin{array}{l}\text { TY } \\
\text { M \& PM }\end{array}$ & $\begin{array}{l}\text { Common } \\
\text { Moderate }\end{array}$ \\
\hline J. Agardh & Gracilariaceae & $M \& P M$ & Moderate \\
\hline $\begin{array}{l}\text { 40. Grateloupia filicina (J.V. Lamour.) } \\
\text { C.Agardh }\end{array}$ & $\begin{array}{l}\text { Cryptomaniales / } \\
\text { Halymeniaceae }\end{array}$ & $M \& P M$ & Moderate \\
\hline 41. Grateloupia lithophila Boergesen & & $\mathrm{M} \& \mathrm{PM}$ & Moderate \\
\hline $\begin{array}{l}\text { 42. Amphiroa fragilissima (L.) } \\
\text { J.V. Lamour. } \\
\text { 43. Jania spectabilis (Harv. ex Grunow) }\end{array}$ & $\begin{array}{l}\text { Corallinales / } \\
\text { Corallinaceae }\end{array}$ & $\mathrm{PM} \& \mathrm{~S}$ & Scanty \\
\hline J.H.Kim, Guiry \& H.-G.Choi & & $\mathrm{S}$ & Scanty \\
\hline $\begin{array}{l}\text { 44. Chondracanthus acicularis (Roth) } \\
\text { Fredericq }\end{array}$ & $\begin{array}{l}\text { Gigartinales / } \\
\text { Gigartinaceae }\end{array}$ & $\mathrm{PM}$ & Scanty \\
\hline $\begin{array}{l}\text { 45. Hypnea musciformis (Wulfen) } \\
\text { J.V. Lamour. }\end{array}$ & Hypneaceae & TY & Common \\
\hline 46. Hypnea spinella (C.Agardh) Kuetz. & & M \& PM & Scanty \\
\hline 47. Hypnea valentiae (Turner) Mont. & & $\mathrm{S}$ & Scanty \\
\hline 48. Champia compressa Harv. & $\begin{array}{l}\text { Rhodymeniales / } \\
\text { Champiaceae }\end{array}$ & $\mathrm{PM} \& \mathrm{~S}$ & Scanty \\
\hline $\begin{array}{l}\text { 49. Ceratodictyon variabile (J. Agardh) } \\
\text { R.E.Norris[Gelidiopsis repens (Kuetz.) } \\
\text { Weber-Van Bory] }\end{array}$ & Rhodymeniaceae & $\mathrm{S}$ & Moderate \\
\hline $\begin{array}{l}\text { 50. Centroceras clavulatum (C. Agardh) } \\
\text { Mont. }\end{array}$ & Ceramiales / Ceramiaceae & TY & Common \\
\hline $\begin{array}{l}\text { 51. Gayliella flaccida (Harv. ex Kuetz) } \\
\text { T.O. Cho \& L.J. McIvor } \\
\text { [Ceramium flaccidum (Kuetz.) Ardiss.] }\end{array}$ & & TY & Scanty \\
\hline $\begin{array}{l}\text { 52. Melanothamnus platycarpus } \\
\text { (Boergesen) Díaz-Tapia \& Maggs } \\
\text { [Polysiphonia platycarpa } \text { Boergesen] }\end{array}$ & Rhodomelaceae & $\mathrm{PM} \& \mathrm{~S}$ & Scanty \\
\hline
\end{tabular}

*\{M: Monsoon; PM: Post Monsoon; S: Summer; TY: Throughout Year; [ ]: synonym\}

and Publication Section, Headquarters, Kolkata and the Head of Office, Botanical Survey of India, Southern Regional Centre, Coimbatore for facilities and encouragements. We are also thankful to the Coast Guard, Udupi, Karnataka for kind permission and assistance during the study period.

\section{REFERENCES}

BRUMMITT, R.K. AND C.E. POWELL 1992. Authors of Plant Names. Royal Botanic Gardens, Kew. 1-736 pp.
DESIKACHARY, T.V., V. KRISHNAMURTHY AND M.S. BALAKRISHNAN 1990. Rhodophyta Vol. II- PartIIA. Madras Science Foundation, Chennai, India. 279 pp.

DESIKACHARY, T.V., V. KRISHNAMURTHY AND M.S. BALAKRISHNAN 1998. Rhodophyta Vol. II. Part-II B. Madras Science Foundation, Chennai, India. 359 pp.

HUISMAN, J.M. 2015. Algae of Australia: Marine Benthic Algae of North-wesetrn Australia, 1: Green and Brown 
Algae. CSIRO Publishing, Melbourne. 370 pp.

KAMATH, J. 2002. Where rocks tell a tale. The Hindu. 16.09.2002.

KRAFT, G. T. 2007. Algae of Australia: Marine Benthic Algae of Lodr Howe Island and the Southern Great Barrier Reef, 1: Green Algae. CSIRO Publishing, Melbourne, Australia. 356 pp.

KRAFT, G. T. 2009. Algae of Australia: Marine Benthic Algae of Lodr Howe Island and the Southern Great Barrier Reef, 2: Brown Algae. CSIRO Publishing, Melbourne, Australia. 364 pp.

KRISHNAMURTHY, V. AND M. BALUSWAMI 2010. Phaeophyceae of India and neighbourhood. Vol. I, Krishnamurthy Institute of Algology, Chennai. 192 pp.

KRISHNAMURTHY, V. 2000. Algae of India and neighbouring countries I. Chlorophycota; Oxford \& IBH Publishing Co. Pvt. Ltd., New Delhi. 210 pp.

MARKAGER, S. AND K. SAND-JENSEN 1994. The physiology and ecology of light-growth relationship in macroalgae. Prog. Phycol. Res., 10: 210-293.

PALANISAMY, M. AND S.K. YADAV 2017. Eight new additions to marine macro algae flora of Karnataka coast, India. Nelumbo 59 (2): 187-194.

RAO, P.S.N. AND R.K. GUPTA 2015. Algae of India, Vol 3: A checklist of Indian Marine Algae (Excluding Diatoms \& Dinoflagellates) Botanical Survey of India, Kolkata. 1-93 pp.
SILVA, P.C., P.W. BASSON AND R. L. MOE 1996. Catalogue of the benthic marine algae of the Indian Ocean. University of California press, London. 1259 pp.

SRINIVASAN, K.S. 1969. Phycologia Indica (Icones of Indian Marine Algae) Vol. I Botanical Survey of India, Calcutta. 52 pp.

SRINIVASAN, K.S. 1973. Phycologia Indica (Icones of Indian Marine Algae) Vol. II Botanical Survey of India, Calcutta. 60 pp.

SUBRAMANYA, K.R. 2009. Relative fall in Sea level in parts of South Karnataka Coast. Current Science 75: 727-730.

YADAV, S.K. 2020. A review on the economic potential of seaweeds in India. Int. J. Adv. Res. Biol. Sci. 7(12): 1528.

YADAV, S.K. AND M. PALANISAMY 2020. Eleven new additions to marine macro algal flora of Karnataka coast, India. Nelumbo 62 (1): 90-102.

http://www.algaebase.org; accessed on 20.10.2020.

https://gsi.gov.in/webcenter/portal/OCBIS/pageGeoInfo/ pageGEOTOURISM; accessed on 19.10.2020.

https://www.seaweed.ie/ - Seaweed Site: Information on Marine Algae; accessed on 22.10.2020. 